Article

\title{
Fingerprinting Paranesti Rubies through Oxygen Isotopes
}

\author{
Kandy K. Wang ${ }^{1, *}$, Ian T. Graham ${ }^{1}$, Laure Martin ${ }^{2}$, Panagiotis Voudouris ${ }^{3}{ }^{\mathbb{D}}$, Gaston Giuliani ${ }^{4}$, \\ Angela Lay ${ }^{1}$, Stephen J. Harris ${ }^{1}$ and Anthony Fallick ${ }^{5}$ \\ 1 PANGEA Research Centre, School of Biological, Earth and Environmental Sciences, University of NSW, \\ 2052 Sydney, Australia; i.graham@unsw.edu.au (I.T.G.); angela.lay@unsw.edu.au (A.L.); \\ s.j.harris@student.unsw.edu.au (S.J.H.) \\ 2 Centre for Microscopy Characterisation and Analysis, The University of Western Australia, 6009 Perth, \\ Australia; laure.martin@uwa.edu.au \\ 3 Faculty of Geology and Geoenvironment, National and Kapodistrian University of Athens, 15784 Athens, \\ Greece; voudouris@geol.uoa.gr \\ 4 Université de Lorraine, IRD and CRPG UMR 7358 CNRS-UL, BP 20, 15 rue Notre-Dame-des-Pauvres, \\ 54501 Vandœuvre-lès-Nancy, France; giuliani@crpg.cnrs-nancy.fr \\ 5 Isotope Geosciences Unit, S.U.E.R.C., Rankine Avenue, East Kilbride, Glasgow G75 0QF, UK; \\ anthony.fallick@glasgow.ac.uk \\ * Correspondence: kandy.wang@student.unsw.edu.au; Tel.: +61-411418800
}

Received: 1 December 2018; Accepted: 30 January 2019; Published: 3 February 2019

Abstract: In this study, the oxygen isotope $\left(\delta^{18} \mathrm{O}\right)$ composition of pink to red gem-quality rubies from Paranesti, Greece was investigated using in-situ secondary ionization mass spectrometry (SIMS) and laser-fluorination techniques. Paranesti rubies have a narrow range of $\delta^{18} \mathrm{O}$ values between $\sim 0$ and $+1 \%$ and represent one of only a few cases worldwide where $\delta^{18} \mathrm{O}$ signatures can be used to distinguish them from other localities. SIMS analyses from this study and previous work by the authors suggests that the rubies formed under metamorphic/metasomatic conditions involving deeply penetrating meteoric waters along major crustal structures associated with the Nestos Shear Zone. SIMS analyses also revealed slight variations in $\delta^{18} \mathrm{O}$ composition for two outcrops located just $\sim 500$ m apart: PAR- 1 with a mean value of $1.0 \% \pm 0.42 \%$ and PAR- 5 with a mean value of $0.14 \%$ o $\pm 0.24 \%$. This work adds to the growing use of in-situ methods to determine the origin of gem-quality corundum and re-confirms its usefulness in geographic "fingerprinting".

Keywords: rubies; corundum; in-situ oxygen isotopes; Paranesti Greece; Nestos Shear Zone; Secondary ion mass spectrometry (SIMS)

\section{Introduction}

\subsection{Oxygen Isotopic Studies in Corundums}

Oxygen is an abundant element in the Earth's crust, mantle and fluids. Oxygen consists of three naturally-occurring stable isotopes: ${ }^{16} \mathrm{O}(99.76 \%),{ }^{17} \mathrm{O}(0.04 \%)$ and ${ }^{18} \mathrm{O}(0.2 \%) . \delta^{18} \mathrm{O}$ expressed as Vienna standard mean ocean water (VSMOW) in per mil is the standard for the oxygen isotopic composition which is a measure of the ratio of the stable isotopes oxygen-18 $\left({ }^{18} \mathrm{O}\right)$ and oxygen-16 $\left({ }^{16} \mathrm{O}\right)$. There are numerous applications of oxygen isotope geochemistry including paleoclimatology, urban forensics, geological genesis and many more [1-3]. Oxygen isotope fractionation is a function of the initial Rayleigh evaporation-precipitation cycle, temperature of the system and degree of water-rock interaction and therefore great care must be taken when interpreting oxygen isotope values [4-7]. 
Although worldwide corundum oxygen isotope values have been found in a wide range from $-27 \%$ (Khitostrov, Russia) to $+23 \%$ (Mong Hsu, Myanmar), most are in the range of $+3 \%$ to $+21 \%$ [ [8-10]. This criterion has often been used to determine the geological origin of coloured corundum and especially the gem corundums, rubies and sapphires. $\delta^{18} \mathrm{O}$ has been particularly useful in determining the likely primary geological origin of placer corundums where the primary origin is uncertain [11]. As isotopic fractionation is a function of both temperature and geological processes, oxygen isotope data need to be treated with some degree of caution Thus, there are very few examples where oxygen isotopes have been used to "fingerprint" the geographic location [12].

\subsection{Geological Setting and Sample Background}

The Paranesti rubies are found within the Nestos Shear Zone (NSZ) of the Rhodope Mountain Complex (RMC) in north-eastern Greece (Figure 1). The tectonic and polymetamorphic record of this Northern Aegean region (including the RMC) reflects the Middle Jurassic to Neogene northeast dipping subduction and convergence of the African-Eurasian plates which resulted in the closure of the Tethys Ocean $[13,14]$. The NSZ is thought to be a one of the syn-metamorphic thrusts in the RMC that are responsible for regional metamorphic inversion, placing higher amphibolite-facies intermediate terranes onto upper-greenschist to lower amphibolite-facies rocks of the lower terrane $[15,16]$.

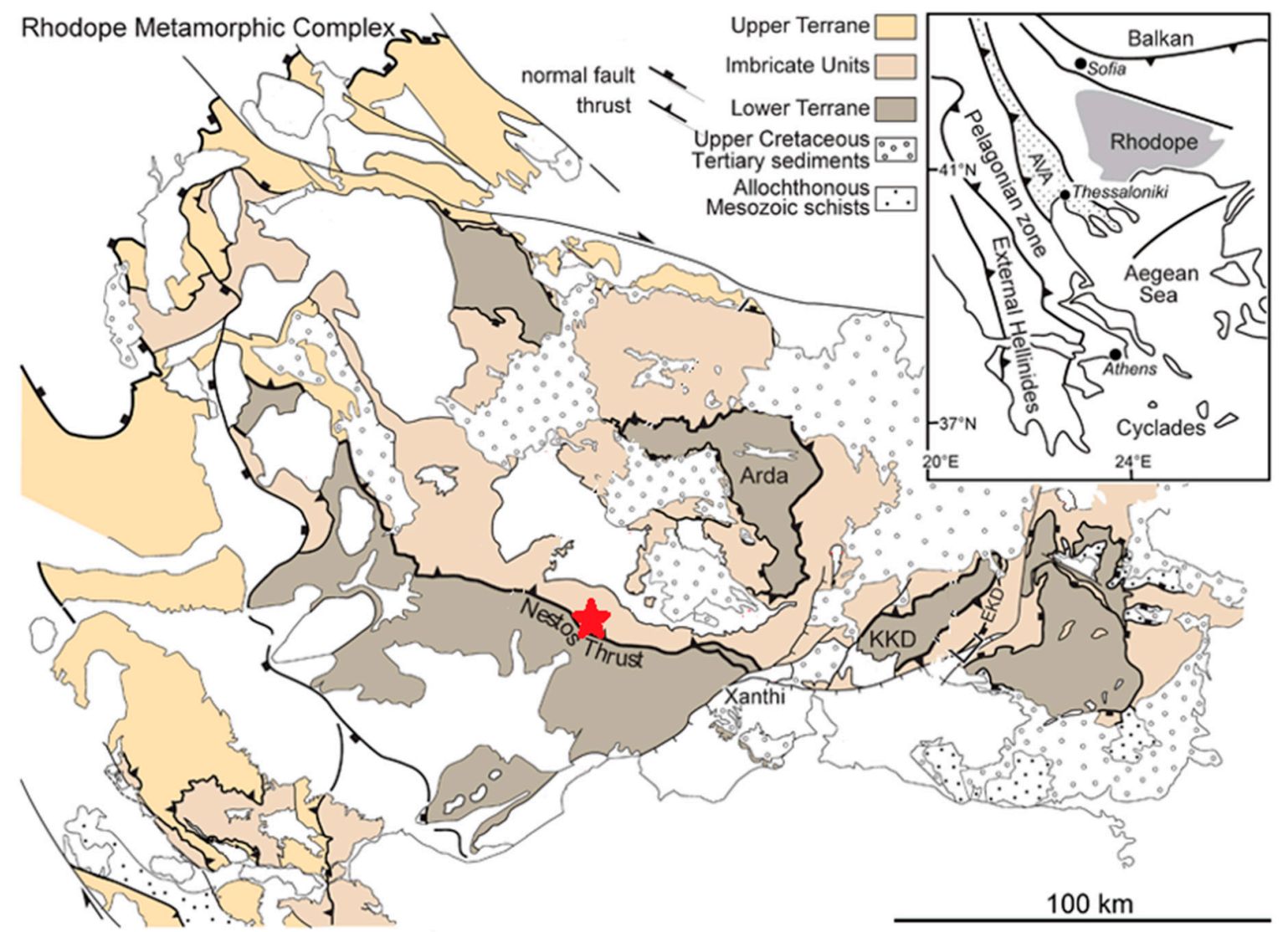

Figure 1. Geological map of the Rhodope Mountain Complex, with Paranesti located within the Nestos Shear Zone (red star) (Adapted from Moulas et al, 2017 [17]).

Based on an earlier systematic study on Paranesti [18], the ruby-bearing occurrences were found to be hosted in pargasite schist with a mafic/ultramafic protolith. The surrounding non-corundum-bearing chlorite schist was found to mainly be comprised of clinochlore. The ruby-bearing occurrence found on the hillside is referred to as PAR-1 (Figure 2a) and the road-side 
occurrence is termed PAR-5 (Figure 2b). Not all of the pargasite boudins nor the pegmatite intrusion found within the vicinity of the two sites contained corundum (Figure 2c,d).

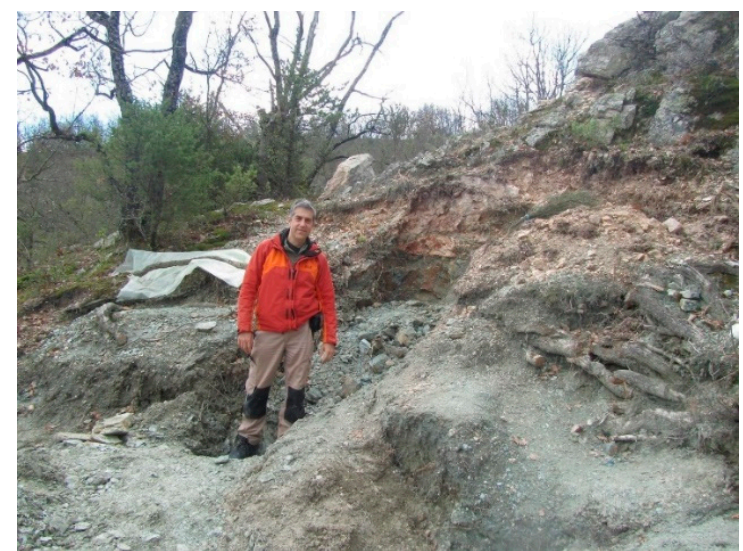

(a)

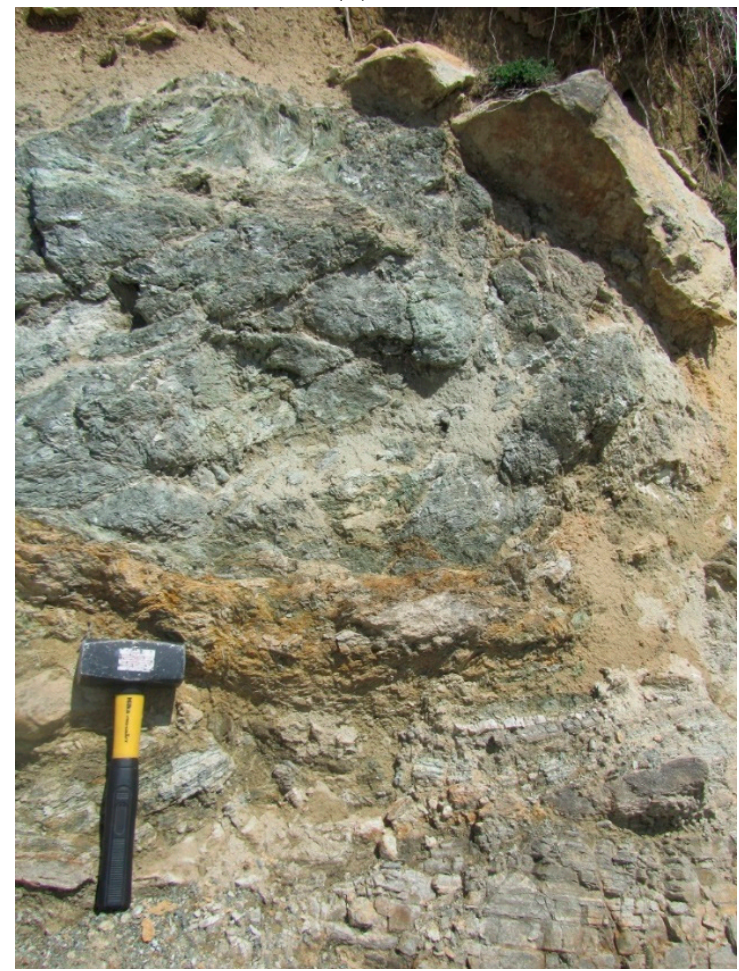

(c)

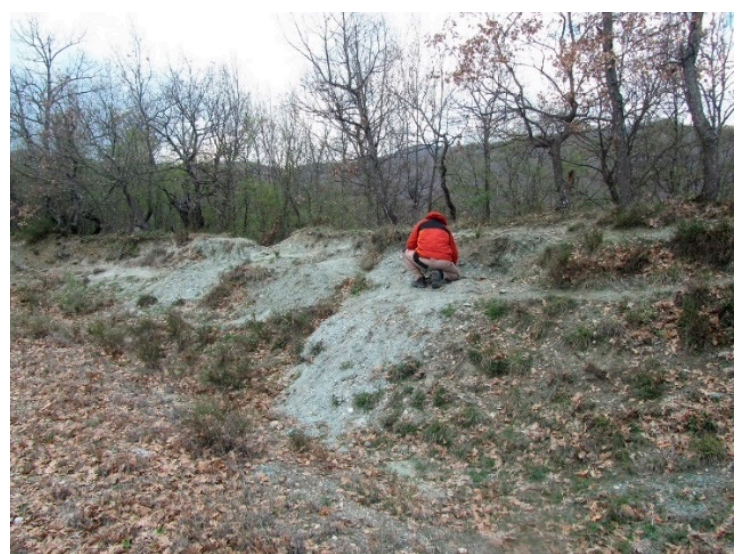

(b)

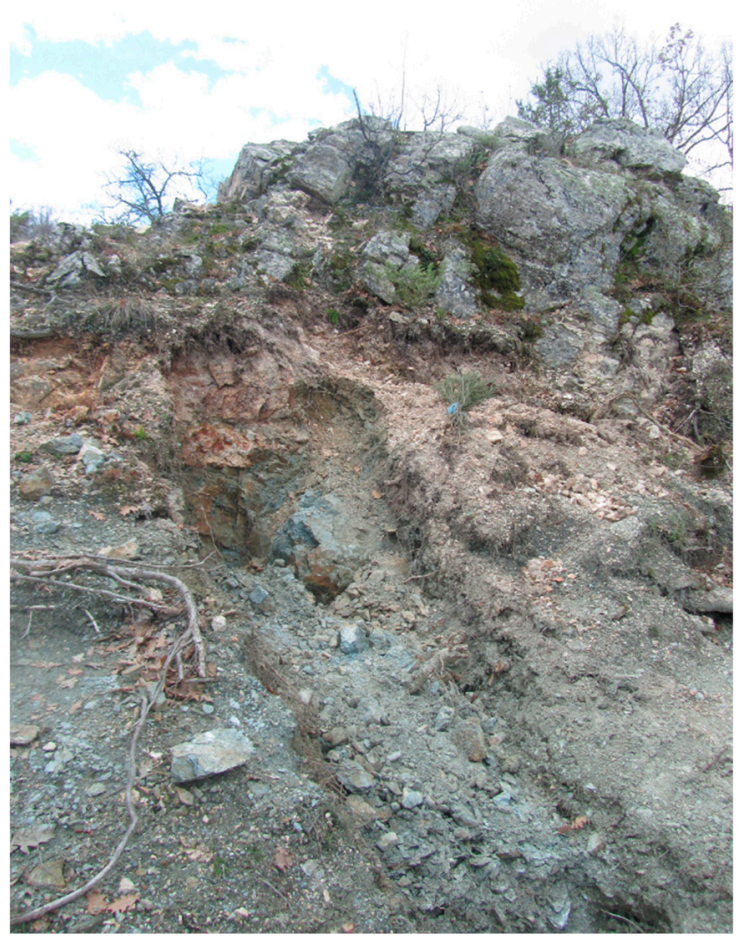

(d)

Figure 2. Locality diagram of the ruby occurrences. (a) PAR-1 location on top of the hill. (b) PAR-5 location on the roadside. (c) Pargasite schist boudin found approx. $500 \mathrm{~m}$ north of PAR-5 without any corundum. (d) Pegmatite on top of the ruby-bearing pargasite schist at PAR-1.

A summary of the main findings from this previous study is listed in Table 1. Detailed LA-ICP-MS trace element analyses showed that the rubies are of metamorphic origin (Figure 3a) with minor partial metasomatic influences (Figure $3 \mathrm{~b}$ ). The high $\mathrm{R}^{2}$ value based on the Fe/Mg vs Ga/Mg elemental discrimination diagram shows both PAR-1 and PAR-5 rubies to contain highly consistent trace element compositions (Figure 3a). 
Table 1. Summary of prior Paranesti ruby results (Wang et al. 2017 [18]).

\begin{tabular}{ccc}
\hline Attributes & PAR-1 & PAR-5 \\
Site & Physical Characteristics & \\
Grain-size & Hillside surface outcrop & Roadside surface outcrop-500 m east of PAR1 \\
Colour & 10 mm-20 mm & 5 mm-10 mm \\
Inclusions & Deeper red than PAR-5 (generally) & Medium red \\
Microscope view & Spinels & None \\
Host rock & More fractured, finer-grained & - \\
& Pargasite schist & Pargasite schist \\
$\mathrm{Cr}_{2} \mathrm{O}_{3}$ & EMPA Analyses (wt. \%) & \\
$\mathrm{FeO}$ & $0.11-1.68$ & $0.13-0.29$ \\
$\mathrm{TiO}_{2}$ & $0.19-0.73$ & $0.18-0.36$ \\
$\mathrm{Ga}_{2} \mathrm{O}_{3}$ & $0-0.01$ & $0-0.06$ \\
& $0-0.04$ & $0-0.04$ \\
$\mathrm{Cr}$ & LA-ICP-MS: Trace Element Analysis (ppm) & \\
$\mathrm{Fe}$ & $360-2856$ & $4-8627$ \\
$\mathrm{~V}$ & $1572-2664$ & $1833-3822$ \\
$\mathrm{Mg}$ & $1-3$ & $2-5$ \\
$\mathrm{Ti}$ & $7-42$ & $8-376$ \\
$\mathrm{Ga}$ & $6-184$ & $10-190$ \\
$\mathrm{Si}$ & $14-23$ & $13-29$ \\
$\mathrm{Ca}$ & $781-2456$ & $837-2123$ \\
& $769-2119$ & $653-1903$ \\
\hline
\end{tabular}

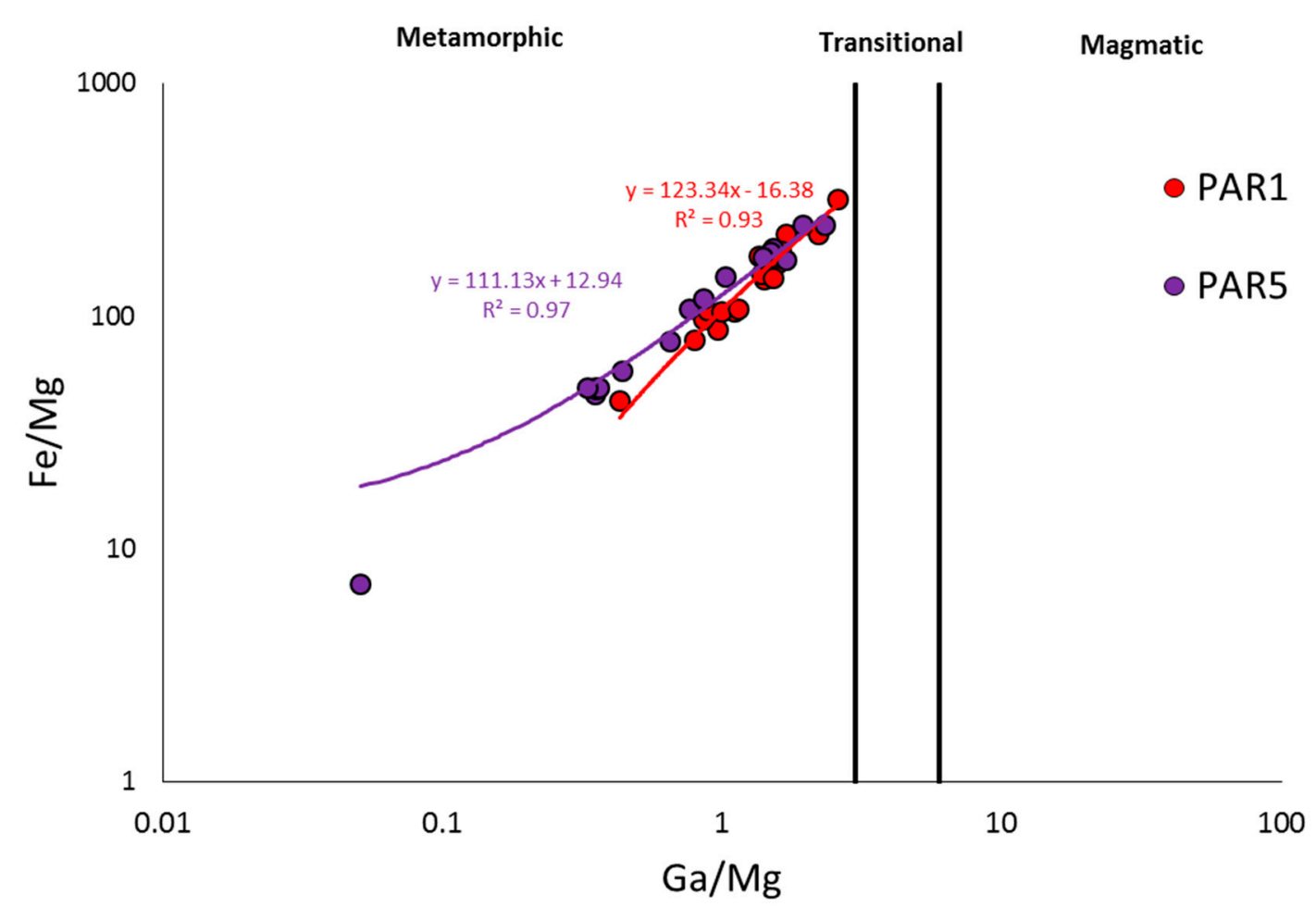

(a)

Figure 3. Cont. 


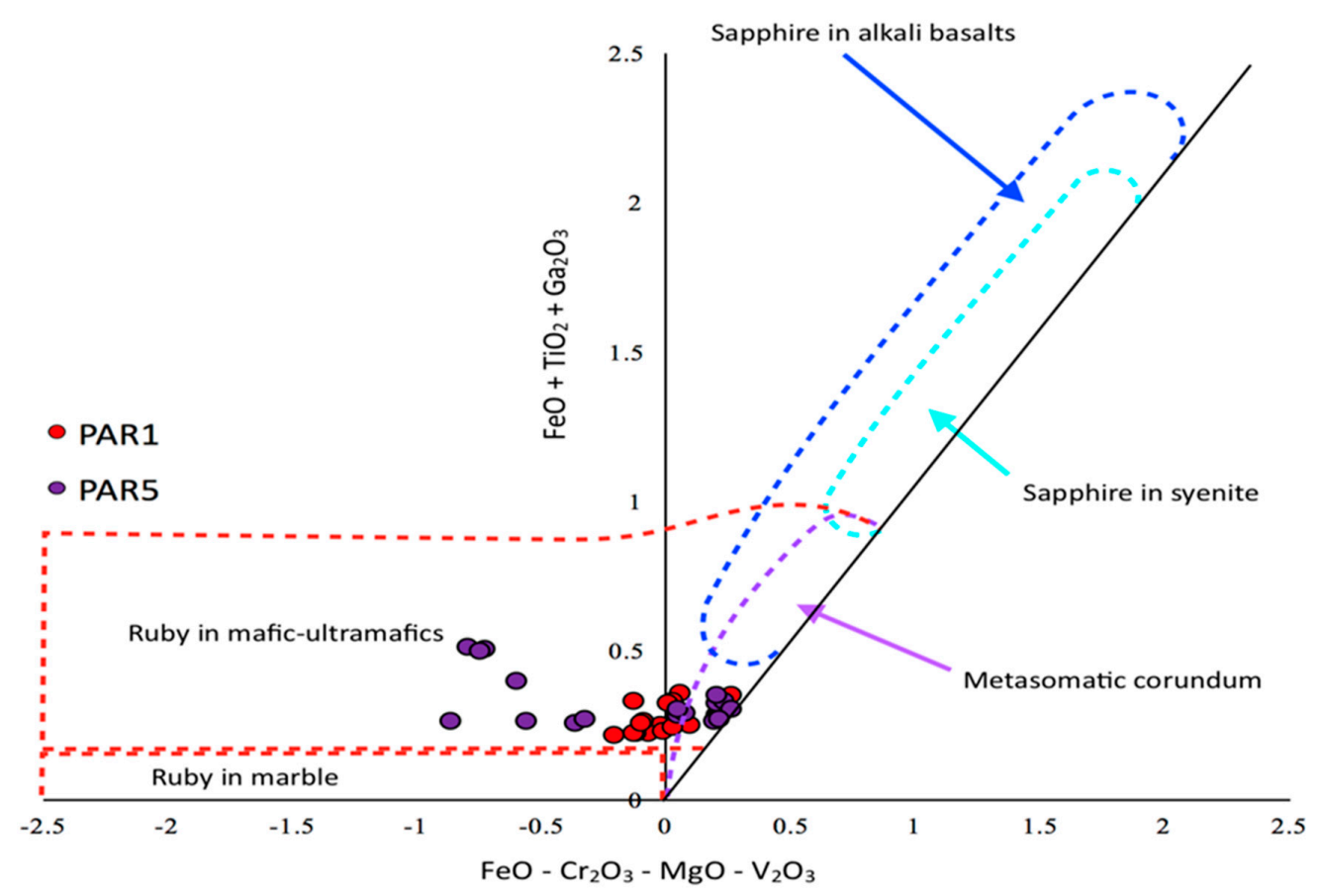

(b)

Figure 3. Trace element discrimination diagrams showing the fields for magmatic, metamorphic and metasomatic corundums, along with the plots for the Paranesti rubies. (a) FeMg vs. GaMg elemental diagram showing the metamorphic vs magmatic fields and SD lines with Paranesti ruby plots. Adapted with permission from Sutherland et al. 2014 [19]. (b) $\mathrm{FeO}+\mathrm{TiO}_{2}+\mathrm{Ga}_{2} \mathrm{O}_{3}$ vs. $\mathrm{FeO}-\mathrm{Cr}_{2} \mathrm{O}_{3}-\mathrm{MgO}-\mathrm{V}_{2} \mathrm{O}_{3}$ elemental diagram showing a metasomatic origin as well as a mafic-ultramafic influence on the Paranesti rubies. Adapted with permission from Giuliani et al. 2014 [20].

\section{Materials and Methods}

Two different oxygen isotopic analytical methods have been used in this study in order to verify the oxygen isotope values of the Paranesti rubies. The rubies were mechanically extracted from the pargasite host matrix and carefully cleaned prior to being sent for analysis. In many samples, the ruby crystals occur in clusters of platy crystals where the grain sizes generally range between $0.5-1.5 \mathrm{~cm}$ (Figure 4a-c). Importantly, in the previous study [18] the ruby grains were generally found to be free of inclusions and thus amenable to in-situ analysis.

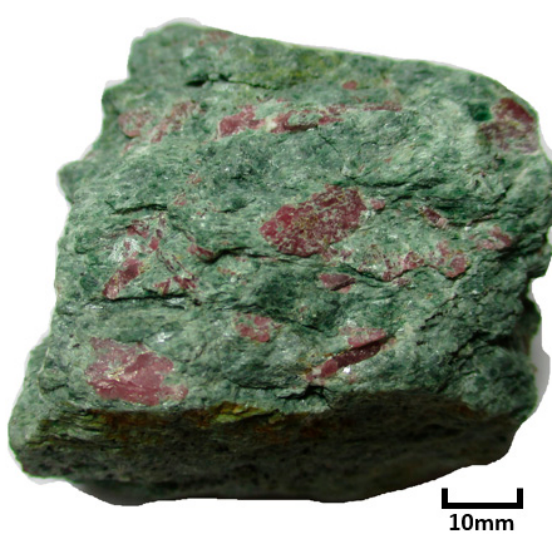

(a)

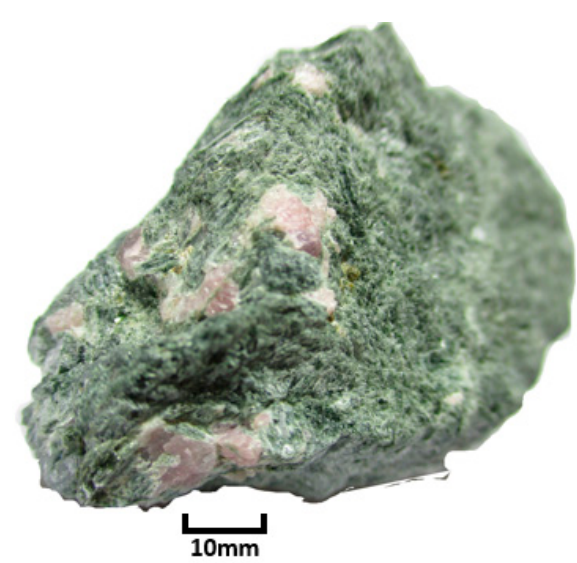

(b)

Figure 4. Cont. 


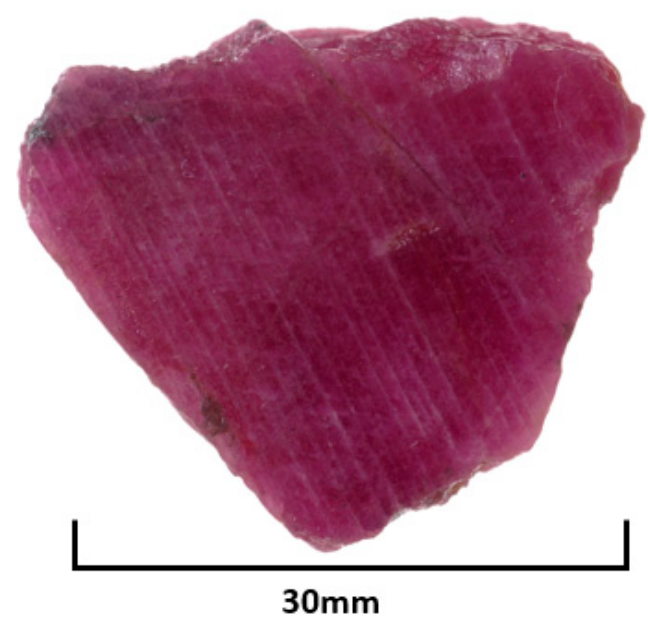

(c)

Figure 4. Images of ruby samples from Paranesti. (a) Dark red ruby samples from PAR-1 in pargasite schist host rock $0.5-1.0 \mathrm{~cm}$; (b) Cluster of pale ruby samples from PAR-5 in pargasite schist host rock 0.5-1.5 cm; (c) Clean PAR-1 ruby sample free from inclusions used for the 2009 Oxygen Isotope analysis.

\subsection{Laser-Fluorination Method (2009)}

In 2009, a reconnaissance study was conducted, whereby five individual grains, one each from different corundum localities/geological environments in Greece, were studied for their $\delta^{18} \mathrm{O}$ composition. These included two colourless to blue sapphires in desilicified pegmatite from Naxos, one pink marble-hosted ruby from Kimi and one purple marble-hosted ruby from Xanthi. One medium red intensity ruby in pargasite schist from Paranesti (PAR-1) was also included. Oxygen isotope analyses were performed using a modification of the laser-fluorination technique described by Sharp [21] that was similar to that applied by Giuliani et al. in 2005 [11].

The method involves the complete reaction of $\sim 1 \mathrm{mg}$ of ground corundum. This powder is then heated by a $\mathrm{CO}_{2}$ laser, with $\mathrm{ClF}_{3}$ as the fluorine reagent. The released oxygen is passed through an in-line Hg-diffusion pump before conversion to $\mathrm{CO}_{2}$ on platinized graphite. The yield is then measured by a capacitance manometer. The gas-handling vacuum line is connected to the inlet system of a dedicated VG PRISM 3 dual inlet isotope-ratio mass spectrometer. All oxygen isotope ratios are reported in $\delta^{18} \mathrm{O}(\%)$ relative to Vienna standard mean ocean water (VSMOW). The secondary standard used for the laser-fluorination method was an internal quartz standard, NBS28 quartz that gave an average $\delta^{18} \mathrm{O}$ value of $9.6 \%$. Oxygen yields differing significantly from the theoretical value of $14.07 \mu \mathrm{mol}$. per mg were taken as likely evidence of analytical artefact. Precision and accuracy on the internal quartz standard are $\pm 0.1 \%(1 \sigma)$. Duplicate and triplicate analyses of sapphire and ruby suggested that this is appropriate for such materials.

\subsection{Secondary Ion Mass Spectrometry (SIMS) Method (2017)}

The 2017 analyses were performed exclusively on a range of coloured ruby grains from the two distinct Paranesti locations described in the previous study [13]. Unlike the 2009 analyses, these analyses were made using secondary ionisation mass spectrometry (SIMS) to analyse different areas of selected ruby grains in-situ to measure oxygen isotope ratios with less than one per mil $(\%)$ level precision. Oxygen isotope ratios $\left({ }^{18} \mathrm{O} /{ }^{16} \mathrm{O}\right)$ in ruby were determined using a Cameca IMS 1280 multi-collector ion microprobe within the Centre for Microscopy, Characterisation and Analysis (CMCA), University of Western Australia (UWA). The materials examined in 2017 included 3 ruby grains from 3 different samples ( 57 analyses) from PAR- 1 and 5 ruby grains from 5 different samples (44 analyses) from PAR-5. Each analysis point is shown in Figure 5a,b. 


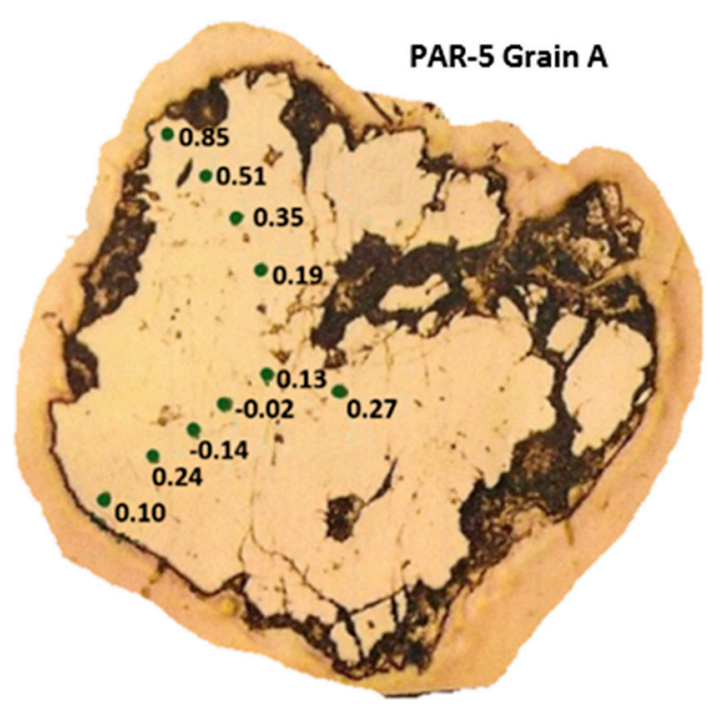

(a)

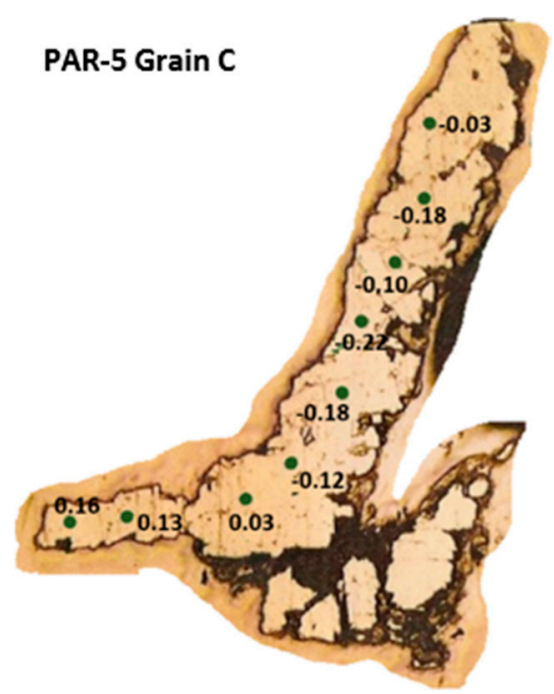

(b)

Figure 5. (a) SIMS in-situ analysis spot location individually marked on the ruby grain-PAR-5 Grain A; (b) SIMS in-situ analysis spot location individually marked on the ruby grain-PAR-5 Grain C.

The sample mounts were carefully cleaned with detergent, distilled water and ethanol in an ultrasonic bath and then coated with gold (30 nm in thickness) prior to SIMS O isotope analyses. For oxygen isotopic analyses, secondary ions were sputtered from the sample by bombarding its surface with a Gaussian $\mathrm{Cs}^{+}$beam and a total impact energy of $20 \mathrm{keV}$. The surface of the sample was rastered with a $2.5 \mathrm{nA}$ primary beam over a $15 \times 15 \mu \mathrm{m}$ area. An electron gun was used to ensure charge compensation during the analyses. Secondary ions were admitted in the double focusing mass spectrometer within a $100 \mu \mathrm{m}$ entrance slit and focused in the centre of a $4000 \mu \mathrm{m}$ field aperture (×100 magnification). They were energy filtered using a $30 \mathrm{eV}$ band pass with a $5 \mathrm{eV}$ gap toward the high-energy side. ${ }^{16} \mathrm{O}$ and ${ }^{18} \mathrm{O}$ were collected simultaneously in multicollection mode in Faraday Cup detectors fitted with $10^{10} \Omega$ and $10^{11} \Omega$, respectively. Each analysis includes a pre-sputtering over a $20 \times 20 \mu \mathrm{m}$ area during $30 \mathrm{~s}$ and the automatic centring of the secondary ions in the field aperture, contrast aperture and entrance slit and consisted of 20 four-second cycles which give an average internal precision of $\sim 0.16 \%$ ( $2 \mathrm{SE}$ ).

External reproducibility during the analytical sessions was evaluated by repeating analyses in one single fragment of PAR-1. External reproducibility in this fragment was 0.3 and 0.4 per mil (2SD) during the two analytical sessions. In total, three large fragments of PAR-1 were analysed for their oxygen isotope composition, altogether yielding an average value of $0.9 \pm 0.6$ per mil $(2 \mathrm{SD}, \mathrm{n}=57$, Table 2). Raw oxygen isotope ratios were corrected for instrumental mass fractionation using the $\delta^{18} \mathrm{O}$ composition of PAR-1, which oxygen isotope composition was obtained by laser fluorination method (from the 2009 study). Uncertainty on each $\delta^{18} \mathrm{O}$ spot has been calculated by propagating the errors on instrumental mass fractionation determination, which include the standard deviation of the mean oxygen isotope ratio measured on the primary standard during the session and internal error on each sample data point. Corrected $\delta^{18} \mathrm{O}$ (quoted with respect to Vienna Standard Mean Ocean Water or VSMOW) are presented in Supplementary Material Table S1. 
Table 2. Oxygen isotope results from 2017 using the SIMS method.

\begin{tabular}{ccccc}
\hline Grain & $\boldsymbol{\delta}^{\mathbf{1 8}} \mathbf{O}$ Min & $\boldsymbol{\delta}^{\mathbf{1 8}} \mathbf{O}$ Max & $\boldsymbol{\delta}^{\mathbf{1 8}} \mathbf{O}$ Mean & Number of Analyses \\
\hline PAR-1a & 0.64 & 1.62 & $1.00 \pm 0.42$ & 31 \\
PAR-1b & 0.44 & 1.17 & $0.67 \pm 0.37$ & 13 \\
PAR-1c & 0.77 & 1.68 & $1.27 \pm 0.47$ & 13 \\
\hline PAR-1 Total & 0.44 & 1.68 & $1.00 \pm 0.42$ & 57 \\
\hline PAR-5central & -0.04 & 0.51 & 0.27 & 12 \\
PAR-5a & -0.14 & 0.85 & 0.25 & 8 \\
PAR-5b & -0.31 & 0.42 & 0.03 & 9 \\
PAR-5c & -0.22 & 0.16 & -0.06 & 5 \\
PAR-5d & 0.08 & 0.27 & 0.17 & 44 \\
\hline PAR-5 Total & -0.31 & 0.85 & $0.14 \pm 0.24$ & 93 \\
\hline Combined PAR-1 and PAR-5 & -0.31 & 1.31 & 0.60 &
\end{tabular}

\section{Results}

\subsection{Laser-Fluorination Results}

Using the laser-fluorination method, the oxygen isotope ratio for the pargasite schist hosted PAR-1 ruby was found to be $\delta^{18} \mathrm{O} 1.0 \%$. This analytical run also included a number of rubies and sapphires from different geological environments. Sapphires from desilicified pegmatites were found to range from $4.8 \%$ to $5.0 \%$ and rubies from marble-hosted deposits were found to range from $20 \%$ to $22 \% 0$ (Table 3).

Table 3. Oxygen isotope results from the 2009 reconnaissance using the laser-fluorination method, $\mathrm{n}=1$.

\begin{tabular}{ccccc}
\hline Sample & Location & Sample Type & Deposit Type & $\boldsymbol{\delta}^{\mathbf{1 8}} \mathbf{O}$ \\
\hline NAX2 & Naxos, Greece & Colourless sapphire & Desilicified pegmatite & 4.80 \\
NAX3 & Naxos, Greece & Colourless to blue sapphire & Desilicified pegmatite & 5.05 \\
PAR-1 & Paranesti, Greece & Red ruby & Pargasite schist & 1.00 \\
KIM2 & Kimi, Greece & Pink ruby & Marble-hosted & 20.50 \\
Xanthi & Xanthi, Greece & Purple-pink ruby & Marble-hosted & 22.09 \\
\hline
\end{tabular}

\subsection{Secondary Ionisation Mass Spectrometry (SIMS) Results}

The oxygen isotope ratios $\delta^{18} \mathrm{O}$ (VSMOW) are presented in Table 2. PAR-5 results show values of $-0.31 \%$ to $0.85 \%$ ( $0.14 \pm 0.24)$, on average slightly lower compared to PAR-1 results $0.44 \%$ to $1.68 \%$ o $(1.00 \pm 0.42)$ even though the two occurrences are only $500 \mathrm{~m}$ apart.

\section{Discussion}

\subsection{Corundum Oxygen Isotopes as An Identifier for Geological Origin}

A framework on the interpretation of the geological origin of gem corundums using the $\delta^{18} \mathrm{O}$ ratio proposed by Giuliani et al is now widely adopted [11]. Based on this framework, rubies and pink sapphires can be classified into 5 categories based on their $\delta^{18} \mathrm{O}$ value range.

1. Mafic gneiss hosted from $2.9 \%$ to $3.8 \%$;

2. Mafic-ultramafic rocks (amphibolite, serpentinite) from $3.2 \%$ to $6.8 \%$;

3. Desilicated pegmatites from $4.2 \%$ to $7.5 \%$;

4. Shear zones cross-cutting ultramafic lenses and pegmatites within sillimanite gneisses $11.9 \% 0-13.1 \%$;

5. Marble-hosted rubies $16.3 \% 0-23 \%$. This framework has been further validated by numerous subsequent corundum oxygen isotope studies [22-25]. 
The reconnaissance 2009 laser fluorination results on the sapphires and rubies from different geological environments very closely fits the oxygen isotope value ranges from the model of Giuliani et al. where over 200 corundum samples were analysed under the same method [1]. That is the marble-hosted value from $20 \%$ to $22 \%$ is within the range of $16.3 \%$ to $23 \%$ and the sapphires from the desilicified pegmatites with a value from $4.8 \%$ to $5 \%$ fits within the framework range from $4.2 \%$ to $7.5 \%$. Therefore, the $\delta^{18} \mathrm{O}$ results obtained using the laser-fluorination method in 2009 are further validated as accurate measurements.

\subsection{PAR-1 vs. PAR-5 Variations}

The oxygen isotope values obtained using SIMS indicates that the Paranesti rubies have a narrow defined band of oxygen isotope signatures with a mean on $+1 \%_{0}$ (ranging from $-0.31 \%_{0}$ to $1.31 \%$ ). This is lower than any ratios based on the existing framework for rubies. There are further distinctive constrained values between PAR-1 (+0.65\% to $1.31 \% 0)$ and PAR-5 $(-0.31 \%$ to $0.85 \%$ ). There is a slight overlap of the individual highest value in PAR-5 to the lowest value in PAR-1. The average for PAR-1 is $+1 \%$ whilst the average for PAR- 5 is $+0.14 \%$.

There may be some differences between core-rim oxygen isotope values observed in the PAR-5 SIMS results where the core average $(-0.02)$ is lower than the rim average $(0.29)$. However, this is within the range of uncertainty when the errors are taken into account. This narrow range within individual localities and between the two localities that are $500 \mathrm{~m}$ apart is in stark contrast to the findings of Bindeman et al (2010) [7] who found variation within single $10 \mathrm{~cm}$ samples of up to 3\% and variation within single ruby grains of up to $1.5 \%$. It also does not rule-out variances due to partitioning in individual crystals during growth. Therefore, a detailed cathodoluminescence analysis to determine the homogeneity or heterogeneity of the sample grains is suggested for future studies. As the traditional laser fluorination method consumes the entire grain, such subtle zoning would not be seen using this technique. Thus, the greater spatial resolution of the SIMS technique enables us to analyse discrete isotopic domains (i.e., rims, cores, sectors) within single corundum crystals.

\subsection{Global Low to Ultra-Low Oxygen Isotope Corundum Comparison}

$\delta^{18} \mathrm{O}(\mathrm{SMOW})$ values for gem corundums below $1 \%$ are very rare and not shown on the original systematic framework by Giuliani et al 2005 [11]. Other than the Paranesti rubies shown above, the only negative value for corundums are from Karelia in north-western Russia and sapphire from a secondary deposit in Madagascar. Table 4 lists the global low to ultra-low oxygen isotope analyses for corundums.

The Madagascar sapphire deposit of Ilakaka with $\delta^{18} \mathrm{O}$ of $-0.3 \%$ to $16.5 \%$ is a consolidated placer formed in a sandstone environment. The geological origin of the different ranges of isotopic values found for the sapphires corresponds to at least five different geological environments [26]. The low $\delta^{18} \mathrm{O}$ delta values for some sapphires correspond up to an unknown geological sapphire type.

The PAR-1 result of $+1.0 \%$ is lower than most known primary corundum oxygen isotope values other than the unique ultra-low values of corundums from Karelia [28,30] and one instance of ruby from the Soamiakatra area of Madagascar [26]. The Karelia corundum formed under unique circumstances (see discussion below) and can be easily distinguished from the Paranesti rubies. The Madagascar rubies show much higher average $\delta^{18} \mathrm{O}$ values and the minimum value obtained corresponds to the maximum value from Paranesti. Therefore, oxygen isotope analysis is a valuable tool that can be used to fingerprint the Paranesti rubies Figure 6 from other worldwide occurrences. 
Table 4. Global comparison of corundums with low oxygen isotope values.

\begin{tabular}{|c|c|c|c|c|c|c|}
\hline Country & District & $\begin{array}{c}\delta^{\mathbf{1 8}} \mathrm{O} \% 0 \\
\text { (Min) }\end{array}$ & $\begin{array}{c}\delta^{18} \mathrm{O} \% 0 \\
(\text { Max) }\end{array}$ & Host Rock & $\begin{array}{l}\text { Primary vs. } \\
\text { Secondary }\end{array}$ & $\begin{array}{c}\text { Corundum } \\
\text { Type }\end{array}$ \\
\hline Greece $^{1}$ & Paranesti-1 * & 0.65 & 1.31 & Pargasite schist & Primary & Ruby \\
\hline Greece $^{1}$ & Paranesti-5* & -0.31 & 0.85 & Pargasite schist & Primary & Ruby \\
\hline Madagascar $^{2}$ & Ilakaka * & -0.30 & 16.5 & Placer in sandstone & Secondary & Sapphire \\
\hline Madagascar $^{2}$ & Andilamena * & 0.50 & 3.9 & Placer in basalt & Secondary & Ruby \\
\hline Russia $3,4,7$ & Khitostrov^ & -26.3 & -17.7 & plagiogneiss & Primary & Corundum \\
\hline Russia $^{7}$ & Khitostrov * & -18.6 & - & Ky-Crn-Pl, leucocratic & Primary & Corundum \\
\hline Russia $^{3}$ & Varastskoye^ & -19.2 & -11.3 & plagiogneiss & Primary & Corundum \\
\hline \multirow[t]{2}{*}{ Russia $^{4}$} & Varastskoye \# & -17.3 & - & Crn-Cam rock, coarse grained & Primary & Corundum \\
\hline & Varastskoye \# & -19.2 & - & Crn and Crn-St-Pl substituting Ky & Primary & Corundum \\
\hline Russia $^{4}$ & Dyadina \# & 0.49 & - & Inclusion of Cam-Crn in giant Gt & Inclusion & Corundum \\
\hline Russia ${ }^{4}$ & Perusel'ka * & 0.26 & 3.45 & Crn-Cam rock, coarse grained & Primary & Corundum \\
\hline Russia $^{5}$ & Perusel'ka \# & 0.6 & - & Corundum-kyanite amphibolite & Primary & Corundum \\
\hline Russia $^{5}$ & Perusel'ka \# & 1.5 & - & Corundum amphibolite & Primary & Corundum \\
\hline Russia $^{5}$ & Notozero * & -1.7 & -1.5 & Ged-Gt rocks with Crn and St & Primary & Corundum \\
\hline Russia $^{4}$ & Mironova Guba^ & $(2.34)$ & - & Cam-Crn rock & Primary & Corundum \\
\hline Thailand ${ }^{6}$ & Bo Rai * & 1.30 & 4.20 & Placer in basalt & Secondary & Ruby \\
\hline
\end{tabular}

* Individual grain analysis ^ Whole-rock analysis \# Only one analysis result, no range. Bi-biotite, Cam-Ca-amphibole, Crn—corundum, Ged—gedrite amphibole, Gt—garnet, Ky-kyanite, Pl—plagioclase, Prg — pargasitic amphibole, St—staurolite. ${ }^{1}$ Wang et al. (2017) [18]; ${ }^{2}$ Giuliani et al. (2007) [26]; ${ }^{3}$ Vysotskiy et al. (2015) [27]; ${ }^{4}$ Bindeman and Serebryakov (2011) [28]; ${ }^{5}$ Vysotskiy et al. (2014) [12]; ${ }^{6}$ Yui et al. (2006) [29];

${ }^{7}$ Bindeman et al. (2010) [7].

LOW - ULTRA-LOW OXYGEN ISOTOPE PRIMARY RUBIES COMPARISON WORLDWIDE

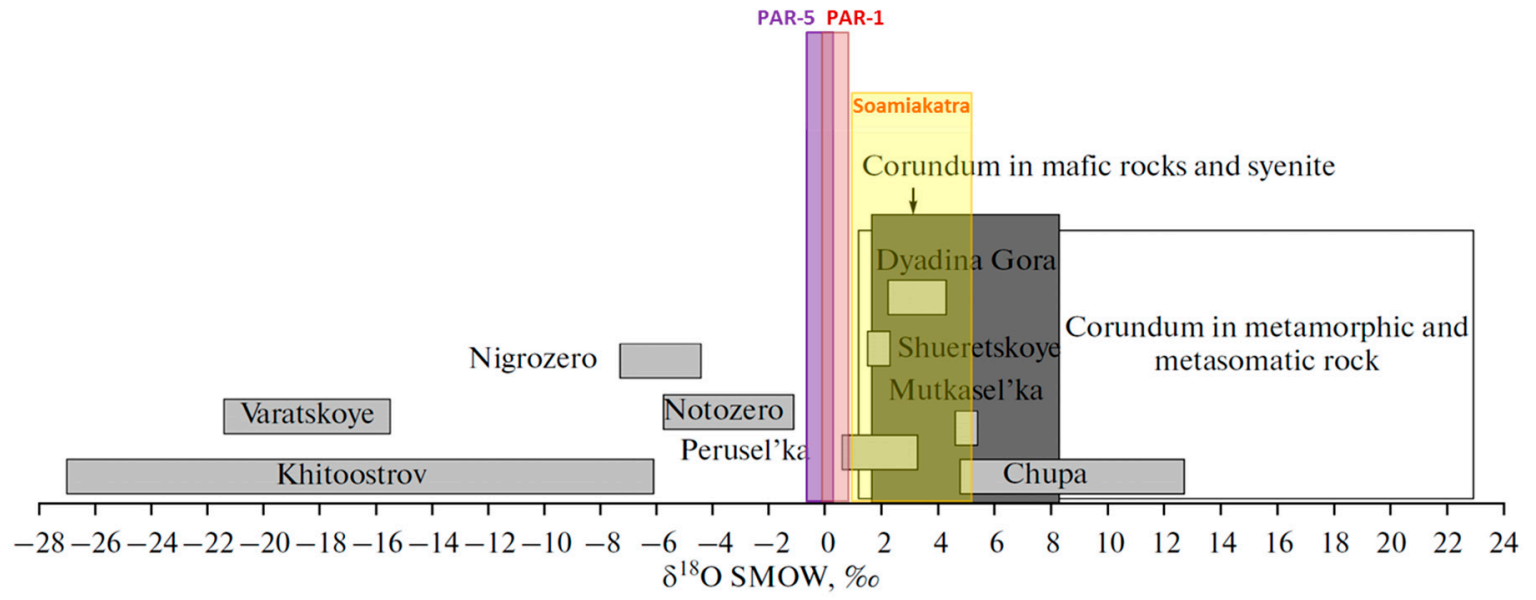

Figure 6. Oxygen isotopic comparison of rubies from Paranesti occurrences compared with low $\delta^{18} \mathrm{O}$ corundums from Karelia in northwestern Russia and Soamiakatra in Madagascar.

\subsection{Possible Causes for Low Oxygen Isotope Corundum Formation}

There are several current hypotheses on how corundums can form with low $\delta^{18} \mathrm{O}$ isotope ratios. These range from hydrothermal alteration of deeply penetrating surface meteoric waters to isotope separation by thermal diffusion during endogenous fluid flow [31,32].

\subsubsection{Kinetic Isotope Fractionation}

Kinetic isotope fractionation occurs when rapid thermal decomposition of hydrous phases results in isotope disproportionation into a high- $\delta^{18} \mathrm{O}$ residue and a low- $\delta^{18} \mathrm{O}$ fluid $[33,34]$. However, 
the high- $\delta^{18} \mathrm{O}$ residue material should also be found within proximity of the studied samples for this hypothesis to apply. The water-rock interaction is kinetically restricted in supracrustal rocks and isotope fractionation factors are large at low temperatures, favouring higher- $\delta^{18} \mathrm{O}$ solids [35]. In contrast, isotopic exchange is more rapid within a hydrothermal system. As the Paranesti rubies formed under amphibolite-facies conditions above $600{ }^{\circ} \mathrm{C}$ [18], significant kinetic isotope fractionation is highly unlikely and therefore rules out this hypothesis.

\subsubsection{Thermal Diffusion}

For thermal diffusion, the oxygen in a temperature gradient is redistributed with low $\delta^{18} \mathrm{O}$ at the hotter end and high $\delta^{18} \mathrm{O}$ at the colder end of melt or hydrous solution [31]. Akimova (2015) [32] has proposed a model of cascading thermo-diffusion within shear zones to explain the Karelian ultra-low $\delta^{18} \mathrm{O}$ corundums. This scenario would require several individual thermal cells to align in the correct position simultaneously with a similar convection rate and timing. Given that only two locations have shown ruby-bearing pargasite schist with other very similar pargasite boudins nearby being ruby absent, this model appears to be less likely than the hydrothermal scenario.

\subsubsection{Other Ultra-Low $\delta^{18} \mathrm{O}$ Protoliths}

Ultra-low $\delta^{18} \mathrm{O}$ protoliths could potentially provide the low $\delta^{18} \mathrm{O}$ during corundum syn-metamorphic formation [35]. However, a source for the ultra-low $\delta^{18} \mathrm{O}$ protolith would be needed under this scenario such as a low $\delta^{18} \mathrm{O}$ mantle reservoir or previously surface-exposed and then rapidly buried metamorphic rocks. Neither were observed at Paranesti. As oxygen isotope analyses were not performed on the whole-rock and associated mineral phases for the Paranesti occurrences, this hypothesis cannot be ruled out.

\subsubsection{Hydrothermal Alteration Model}

This hypothesis involves the conservation of the initial isotopic ratios of the protolith in the corundum-bearing rocks and then isotopic exchange between these rocks and meteoric waters before metamorphism [10]. Wang et al. [18] demonstrated that the rubies from Paranesti were syn-metamorphic and were largely free of inclusions. However, as shown by Bindeman et al (2010) [7], this does not preclude preservation of the initial ratios within the protolith for the Paranesti occurrence. Therefore, it is unlikely that the low isotopic ratios observed within the Paranesti rubies were due to preservation of the initial ratios within the protolith.

For granulite facies metamorphism, Wilson and Banksi (1983) [36] proposed three processes that could produce a low oxygen isotope value. These are (1) pre-granulite reaction between heated seawater and hot basic intrusives or an initial protolith such as a palaeosol for the sapphirine-spinel-(cordierite) assemblages; (2) syn-granulite depletion in ${ }^{18} \mathrm{O}$ related to dehydration during granulite metamorphism and removal of the resultant products of partial melting with a depletion in ${ }^{18} \mathrm{O}$ by up to $2 \%$ or $3 \%$ for the restite; and (3) post-granulite facies metamorphism with recrystallization under the effect of biotite and/or amphibole-metasomatism with depletion in $\delta^{18} \mathrm{O}$ up to $4 \%$. Based on the previous study [18], the Paranesti rubies were found to have formed under amphibolite facies conditions and there is no evidence that they ever reached granulite facies within the specified zone. However, there are other locations within the Rhodope Mountain Complex (RMC) where regional metamorphism reached granulite facies conditions, though these are some distance away from Paranesti and no rubies are known from these locations.

The glacial meltwater influence during formation of corundums was proposed to explain the ultra-low $\delta^{18} \mathrm{O}$ isotopic ratios observed for corundums from Karelia in north-western Russia [10,12,27]. However, there is no evidence suggesting the existence of glaciers in the Mediterranean region based on the reconstruction of the tectonic evolution of the East Mediterranean region since the late Cretaceous [37]. Could the RMC be a higher mountain with glaciers that have melted during ruby genesis? There is no evidence in the literature to suggest such and this would only be a remote 
possibility. Therefore, it is unlikely that a glacial meltwater source played a role during ruby formation at Paranesti. However, it is likely that meteoric water (but not glacial melt) interaction caused by downward flow of surface waters along deep crustal fractures/structures during the formation of the corundum would contribute in producing low $\delta^{18} \mathrm{O}$ values for the Paranesti rubies.

\section{Conclusions}

The in-situ SIMS oxygen isotope analyses on the Paranesti rubies is the first time that a primary (and exclusively) ruby occurrence was found to have $\sim+1 \%$ for its $\delta^{18} \mathrm{O}$-isotope composition. Based on the low $\delta^{18} \mathrm{O}$ value and the local geology, it is most likely that the Paranesti rubies formed under metamorphic/metasomatic conditions involving deeply penetrating meteoric waters along major crustal structures related to the Nestos Shear Zone. PAR-5 is potentially closer to the source of the hydrothermal influence during ruby formation compared to PAR-1 and thus has a lower $\delta^{18} \mathrm{O}$. Importantly, this study shows that in-situ gem corundum oxygen isotope analysis using the SIMS method may be used to determine the likely geographic origin for corundums lacking any provenance details. Importantly, with the SIMS method being only minimally destructive, with the analysis spot $(15 \times 15 \mu \mathrm{m})$ amenable to repolishing, a wider adoption of this technique has important applications/implications for the international gem and jewellery industry. A future area of research would be to apply this methodology for more gem mineral varieties other than corundum and emeralds. The aim of such future work would be to determine if in-situ SIMS oxygen isotope analysis can be used to both better understand gem formation and to see if it can be used to clearly separate the same gem mineral from different geographic locations.

Supplementary Materials: The following are available online at http:/ /www.mdpi.com/2075-163X/9/2/91/s1, Table S1: Secondary Ionisation Mass Spectrometry (SIMS) Results.

Author Contributions: K.K.W. wrote the manuscript and interpreted the results of the analyses. I.T.G. collected the samples, provided technical input, funding and supervised the project. L.M. provided technical input and ran the SIMS analyses. P.V. collected the samples and provided geological expertise on the Paranesti region. G.G. and A.F. coordinated the laser fluorination analyses and provided technical input. A.L. and S.J.H. provided technical input.

Funding: This research received no external funding.

Acknowledgments: The authors would like to thank Joanne Wilde, formerly of the School of Biological, Earth and Environmental Sciences, UNSW Sydney, for making the polished mounts required for SIMS analysis. The authors acknowledge the facilities and the scientific and technical assistance of the Australian Microscopy \& Microanalysis Research Facility at the Centre for Microscopy, Characterisation \& Analysis, The University of Western Australia, a facility funded by the University, State and Commonwealth Governments.

Conflicts of Interest: The authors declare no conflict of interest.

\section{References}

1. Hoefs, J. Stable Isotope Geochemistry; Springer: Berlin/Heidelberg, Germany, 1997; ISBN 9783662033791.

2. Bowen, G.J.; Wassenaar, L.I.; Hobson, K.A. Global application of stable hydrogen and oxygen isotopes to wildlife forensics. Oecologia 2005, 143, 337-348. [CrossRef] [PubMed]

3. Miller, K.G.; Fairbanks, R.G.; Mountain, G.S. Tertiary oxygen isotope synthesis, sea level history and continental margin erosion. Paleoceanography 1987, 2, 1-19. [CrossRef]

4. Criss, R.E.; Taylor, H.P., Jr. Meteoric-hydrothermal systems. Rev. Mineral. 1986, 16, 373-424.

5. Valley, J.W. Stable Isotope Thermometry at High Temperatures. Rev. Mineral. Geochem. 2001, 43, $365-413$. [CrossRef]

6. Bindeman, I. Oxygen Isotopes in Mantle and Crustal Magmas as Revealed by Single Crystal Analysis. Rev. Mineral. Geochem. 2008, 69, 445-478. [CrossRef]

7. Bindeman, I.N.; Schmitt, A.K.; Evans, D.A.D. Limits of hydrosphere-lithosphere interaction: Origin of the lowest-known $\delta^{18} \mathrm{O}$ silicate rock on Earth in the Paleoproterozoic Karelian rift. Geology 2010, 38, 631-634. [CrossRef] 
8. Giuliani, G.; Ohnenstetter, D.; Garnier, V.; Fallick, A.E.; Rakotondrazafy, M.; Schwarz, D. The geology and genesis of gem corundum deposits. In Geology of Gem Deposits; Groat, L.A., Ed.; Mineralogical Association of Canada: Québec, QC, Canada, 2007; Volume 37, pp. 23-78. ISBN 9780921294375.

9. Yui, T.-F.; Khin, Z.; Limtrakun, P. Oxygen isotope composition of the Denchai sapphire, Thailand: A clue to its enigmatic origin. Lithos 2003, 67, 153-161. [CrossRef]

10. Krylov, D.P.; Glebovitsky, V.A. Oxygen isotopic composition and nature of fluid during the formation of high-Al corundum-bearing rocks of Mt. Dyadina, northern Karelia. Doklady Earth Sci. 2007, 413, 210-212. [CrossRef]

11. Giuliani, G.; Fallick, A.E.; Garnier, V.; France-Lanord, C.; Ohnenstetter, D.; Schwarz, D. Oxygen isotope composition as a tracer for the origins of rubies and sapphires. Geology 2005, 33, 249. [CrossRef]

12. Vysotskiy, S.V.; Ignat'ev, A.V.; Levitskii, V.I.; Nechaev, V.P.; Velivetskaya, T.A.; Yakovenko, V.V. Geochemistry of stable oxygen and hydrogen isotopes in minerals and corundum-bearing rocks in northern Karelia as an indicator of their unusual genesis. Geochem. Int. 2014, 52, 773-782. [CrossRef]

13. Bonev, N.; Burg, J.-P.; Ivanov, Z. Mesozoic-Tertiary structural evolution of an extensional gneiss dome-The Kesebir-Kardamos dome, eastern Rhodope (Bulgaria-Greece). Int. J. Earth Sci. 2006, 95, 318-340. [CrossRef]

14. Krenn, K.; Bauer, C.; Proyer, A.; Mposkos, E.; Hoinkes, G. Fluid entrapment and reequilibration during subduction and exhumation: A case study from the high-grade Nestos shear zone, Central Rhodope, Greece. Lithos 2008, 104, 33-53. [CrossRef]

15. Barr, S.R.; Temperley, S.; Tarney, J. Lateral growth of the continental crust through deep level subduction-accretion: A re-evaluation of central Greek Rhodope. Lithos 1999, 46, 69-94. [CrossRef]

16. Nagel, T.J.; Schmidt, S.; Janák, M.; Froitzheim, N.; Jahn-Awe, S.; Georgiev, N. The exposed base of a collapsing wedge: The Nestos Shear Zone (Rhodope Metamorphic Province, Greece): The Nestos Shear Zone. Tectonics 2011, 30. [CrossRef]

17. Moulas, E.; Schenker, F.L.; Burg, J.-P.; Kostopoulos, D. Metamorphic conditions and structural evolution of the Kesebir-Kardamos dome: Rhodope metamorphic complex (Greece-Bulgaria). Int. J. Earth Sci. 2017, 106, 2667-2685. [CrossRef]

18. Wang, K.K.; Graham, I.T.; Lay, A.; Harris, S.J.; Cohen, D.R.; Voudouris, P.; Belousova, E.; Giuliani, G.; Fallick, A.E.; Greig, A. The Origin of a New Pargasite-Schist Hosted Ruby Deposit from Paranesti, Northern Greece. Can. Mineral. 2017, 55, 535-560. [CrossRef]

19. Sutherland, F.; Zaw, K.; Meffre, S.; Yui, T.-F.; Thu, K. Advances in Trace Element "Fingerprinting" of Gem Corundum, Ruby and Sapphire, Mogok Area, Myanmar. Minerals 2014, 5, 61-79. [CrossRef]

20. Giuliani, G.; Ohnenstetter, D.; Fallick, A.E. The geology and genesis of gem corundum deposits. In Geology of Gem Deposits. Series: Mineralogical Association of Canada Short Course Series, 44; Groat, L.A., Ed.; Mineralogical Association of Canada: Québec, QC, Canada, 2014; pp. 35-112. ISBN 9780921294542.

21. Sharp, Z.D. In situ laser microprobe techniques for stable isotope analysis. Chem. Geol. 1992, 101, 3-19. [CrossRef]

22. Garnier, V.; Giuliani, G.; Ohnenstetter, D.; Fallick, A.E.; Dubessy, J.; Banks, D.; Vinh, H.Q.; Lhomme, T.; Maluski, H.; Pêcher, A.; et al. Marble-hosted ruby deposits from Central and Southeast Asia: Towards a new genetic model. Ore Geol. Rev. 2008, 34, 169-191. [CrossRef]

23. Zaw, K.; Sutherland, L.; Yui, T.-F.; Meffre, S.; Thu, K. Vanadium-rich ruby and sapphire within Mogok Gemfield, Myanmar: Implications for gem color and genesis. Miner. Deposita 2015, 50, 25-39. [CrossRef]

24. Graham, I.; Sutherland, L.; Zaw, K.; Nechaev, V.; Khanchuk, A. Advances in our understanding of the gem corundum deposits of the West Pacific continental margins intraplate basaltic fields. Ore Geol. Rev. 2008, 34, 200-215. [CrossRef]

25. Sutherland, F.L.; Duroc-Danner, J.M.; Meffre, S. Age and origin of gem corundum and zircon megacrysts from the Mercaderes-Rio Mayo area, South-west Colombia, South America. Ore Geol. Rev. 2008, 34, 155-168. [CrossRef]

26. Giuliani, G.; Fallick, A.; Rakotondrazafy, M.; Ohnenstetter, D.; Andriamamonjy, A.; Ralantoarison, T.; Rakotosamizanany, S.; Razanatseheno, M.; Offant, Y.; Garnier, V.; et al. Oxygen isotope systematics of gem corundum deposits in Madagascar: Relevance for their geological origin. Miner. Deposita 2007, 42, 251-270. [CrossRef] 
27. Vysotskiy, S.V.; Nechaev, V.P.; Kissin, A.Y.; Yakovenko, V.V.; Ignat'ev, A.V.; Velivetskaya, T.A.; Sutherland, F.L.; Agoshkov, A.I. Oxygen isotopic composition as an indicator of ruby and sapphire origin: A review of Russian occurrences. Ore Geol. Rev. 2015, 68, 164-170. [CrossRef]

28. Bindeman, I.N.; Serebryakov, N.S. Geology, Petrology and O and H isotope geochemistry of remarkably ${ }^{18} \mathrm{O}$ depleted Paleoproterozoic rocks of the Belomorian Belt, Karelia, Russia, attributed to global glaciation 2.4 Ga. Earth Planet. Sci. Lett. 2011, 306, 163-174. [CrossRef]

29. Yui, T.-F.; Wu, C.-M.; Limtrakun, P.; Sricharn, W.; Boonsoong, A. Oxygen isotope studies on placer sapphire and ruby in the Chanthaburi-Trat alkali basaltic gemfield, Thailand. Lithos 2006, 86, 197-211. [CrossRef]

30. Krylov, D.P. Anomalous ${ }^{18} \mathrm{O} /{ }^{16} \mathrm{O}$ ratios in the corundum-bearing rocks of Khitostrov, northern Karelia. Doklady Earth Sci. 2008, 419, 453-456. [CrossRef]

31. Bindeman, I.N.; Lundstrom, C.C.; Bopp, C.; Huang, F. Stable isotope fractionation by thermal diffusion through partially molten wet and dry silicate rocks. Earth Planet. Sci. Lett. 2013, 365, 51-62. [CrossRef]

32. Akimova, E.Y.; Lokhov, K.I. Ultralight Oxygen in Corundum-Bearing Rocks of North Karelia, Russia, as a Result of Isotope Separation by Thermal Diffusion (Soret Effect) in Endogenous Fluid Flow. J. Mater. Sci. Chem. Eng. 2015, 3, 42-47. [CrossRef]

33. Clayton, R.N.; Mayeda, T.K. Kinetic Isotope Effects in Oxygen in the Laboratory Dehydration of Magnesian Minerals. J. Phys. Chem. 2009, 113, 2212-2217. [CrossRef]

34. Mendybayev, R.A.; Richter, F.M.; Spicuzza, M.J.; Davis, A.M. Oxygen isotope fractionation during evaporation of Mg- and Si- rich CMAS-liquid in vacuum. Lunar Planet. Inst. Sci. Conf. Abstr. 2010, $41,2725$.

35. Bindeman, I.N.; Serebryakov, N.S.; Schmitt, A.K.; Vazquez, J.A.; Guan, Y.; Azimov, P.Y.; Astafiev, B.Y.; Palandri, J.; Dobrzhinetskaya, L. Field and microanalytical isotopic investigation of ultradepleted in ${ }^{18} \mathrm{O}$ Paleoproterozoic "Slushball Earth" rocks from Karelia, Russia. Geosphere 2014, 10, 308-339. [CrossRef]

36. Wilson, A.F.; Baksi, A.K. Widespread ${ }^{18} \mathrm{O}$ depletion in some precambrian granulites of Australia. Precambrian Res. 1983, 23, 33-56. [CrossRef]

37. Menant, A.; Jolivet, L.; Vrielynck, B. Kinematic reconstructions and magmatic evolution illuminating crustal and mantle dynamics of the eastern Mediterranean region since the late Cretaceous. Tectonophysics 2016, 675, 103-140. [CrossRef] 